
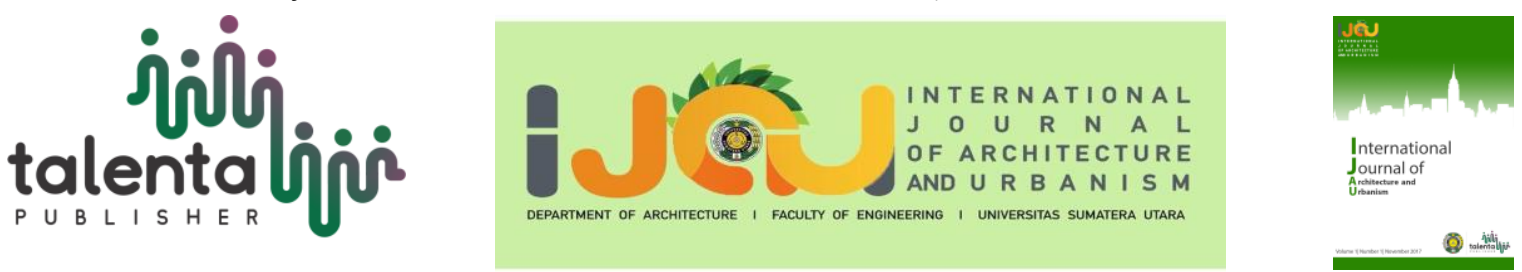

\title{
The Spatial Formation of The Berastagi Sub District, Kabupaten Karo
}

\section{Wendi Prayudi ${ }^{1^{*}}$}

${ }^{1}$ Dinas Sumber Daya Air, Cipta Karya dan Tata Ruang Provinsi Sumatera Utara, Indonesia

\begin{abstract}
Berastagi sub-district is located in the Karo district of North Sumatra province. The majority of people in the Berastagi sub-district are the Karo tribe. The space arrangement settlement is very inspired by grade local culture, makes this area have traditional characteristics. Besides grade culture is very impressive, Berastagi is also be known as a tourism place. In the expected research, settlement can be well-identified it can be was found the spatial formation so that the development of the area will be carried out to be adapted with public expectation. So as the expansion expected can improve the standard of available living in term convenience, harmony and safety to serve life routinely.
\end{abstract}

Keyword: habitation, the spatial formation

Received date month year. | Revised 2 October 2020 | Accepted 18 November 2020

\section{Introduction}

North Sumatera is one of destination area which has noticed beauty criteria very catchy. That beauty criterion is lake, rivers, beaches, waterfalls, nature reserves, forests, hot springs, and others. North Sumatra province is located on a cross position in the trough west pacific area [1]. This region is rich with natural resources and diverse culture society. In this area be found the biggest lake, that is Lake Toba. In the middle of Lake Toba, there is a volcanic island called Samosir island [2].

One of the existing areas in North Sumatera is area Karo district which has a cold air temperature and a beautiful place. This is because the geographic locations are between two mountains that is Sinabung mountain and Sibayak mountain. Karo district is an elevation $1.375 \mathrm{~m}$ above sea level with temperature $19^{\circ} \mathrm{C}$ until to $26^{\circ} \mathrm{C}$ with humidity around $79 \%$ and has mileage distance $65 \mathrm{Km}$ from Medan city as the capital city north Sumatera province [3]. Karo district is located in the highlands of the Bukit Barisan North Sumatra, which geographically has rivers, mountains and lakes [4].

\footnotetext{
*Corresponding author at: Jl. Sakti Lubis No.7, Siti Rejo I, Kec. Medan Kota, Kota Medan, Sumatera Utara 20217

E-mail address: wendiprayudi.wp@gmail.com
}

Copyright (C) 2020 Published by Talenta Publisher, 


\section{Literatur Review}

Karo district has an area of $2.127,25 \mathrm{Km}^{2}$ consisting of 17 sub-district [5]. Most of the land is dry land (field and garden), rice field, forest, grassland, unplanted swamp and much more [6]. Much of the land is a green tourist spot that is cool and beautiful, that is the mainstay of this district. As for the sub-districts in the Karo district, can be seen in the Figure 1.

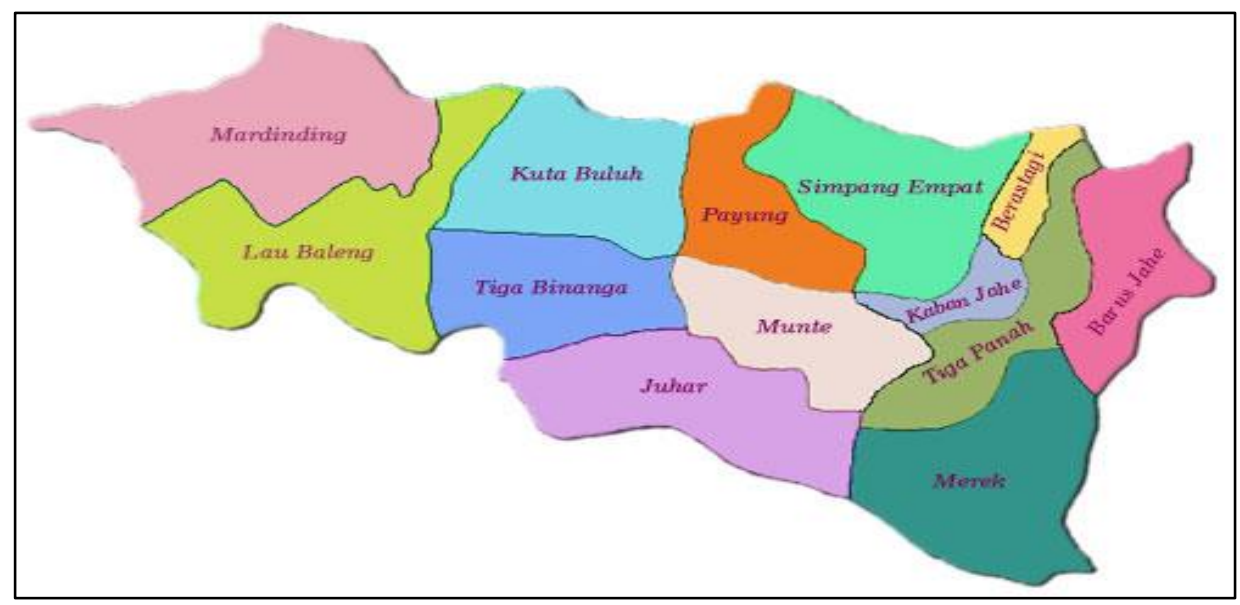

Figure 1 Research Area

One of the most familiar regions in the Karo district is the Berastagi sub-district. Although the Berastagi sub-district is the smallest sub-district in the Karo district, still it has many lands which is used as tourist spot interest often visited the local community and the domestic community [7]. That matter makes Berastagi sub-district have population density level, and residential areas are higher than other sub-districts in Karo district (Figure 2).

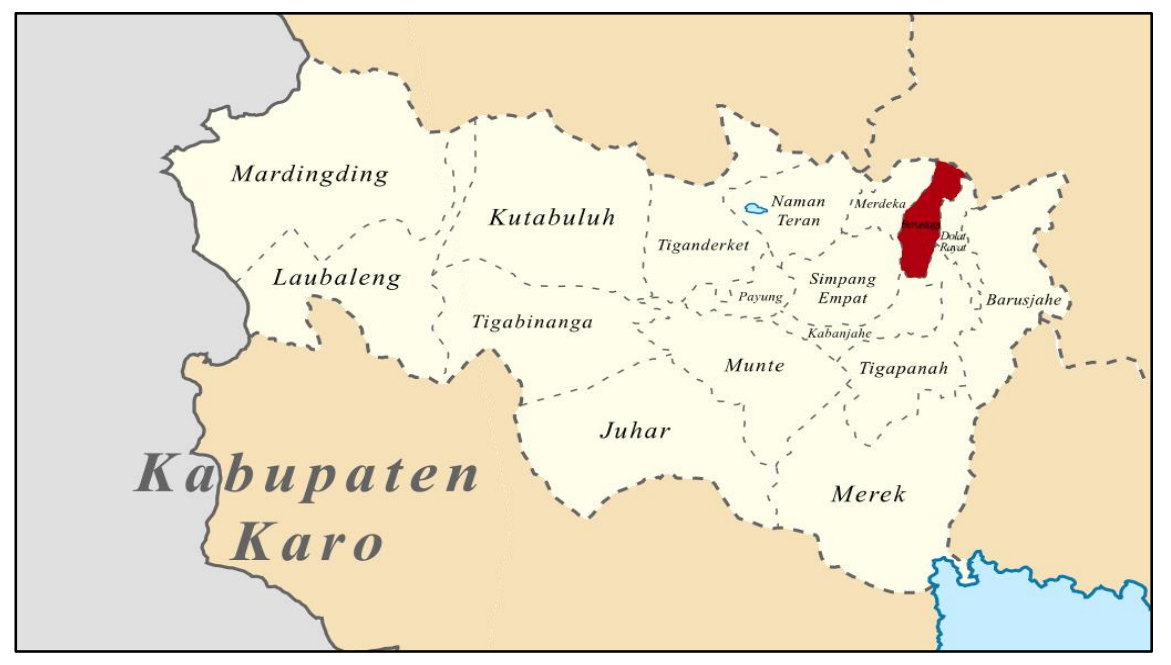

Figure 2 Research Area

The public who lives in Berastagi settlements not only local public from this area, there are also many settlers which makes Berastagi as a place to find a vocation. One of them is to become a trade-in tourist attractions like the Berastagi fruit market, Gundaling hill, highway forest park, 
and many others. Some are working in area travel as a guide or employee in Berastagi subdistrict (Figure 3).

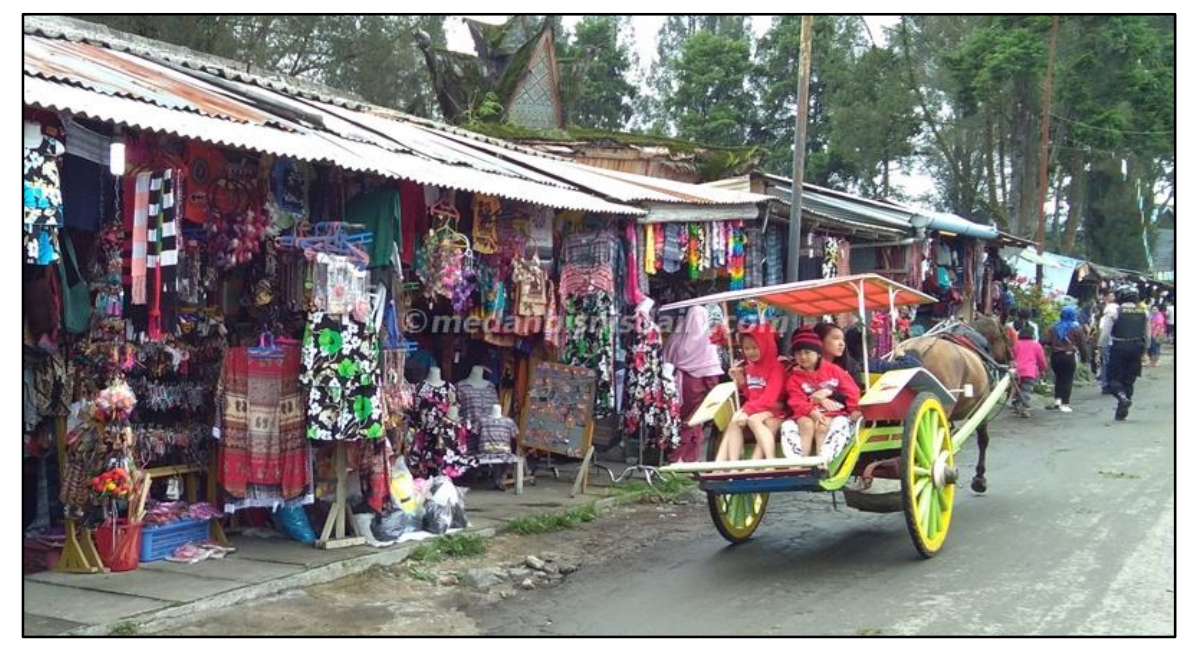

Figure 3 Research Area

The space division concept is based on transcendental values, which are a division of spaces with very basic percentages related to people's belief. This space with transcendental exists in the religious system, system knowledge, system technology and living equipment, relationship genetic system, language, livelihood system, and arts [8]. From the Figure 4, it can be seen how dense the residential population on Berastagi sub-district.

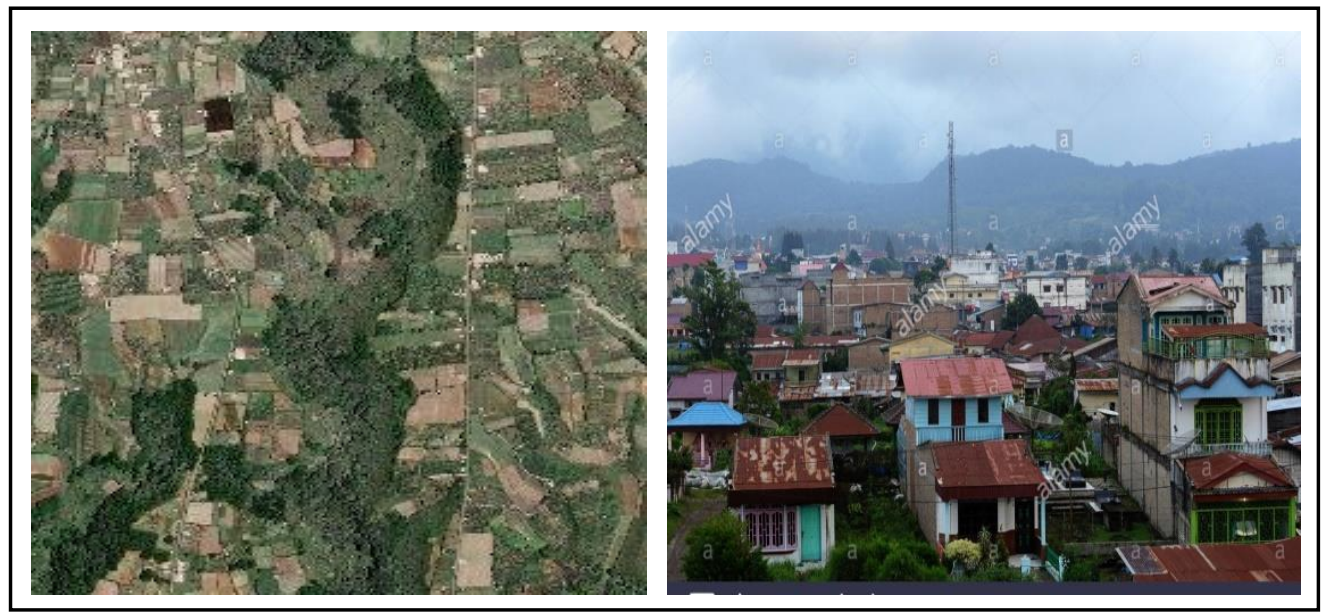

Figure 4 Research Area

Berastagi sub-district region is an area in the Karo district, the majority of the people who live in this region embracing protestant religion, and incidentally is the Karo community [9]. Settlement space arrangement in this area grade powerfully animated, which is sourced from religious regulations and guidelines, they have still appreciated the local culture [10]. The spatial settlement formation in this area the concept mostly apply to Karo culture. The situation in the Berastagi sub-district area that highlights the idea of Karo culture can be seen in the Figure 5 . 


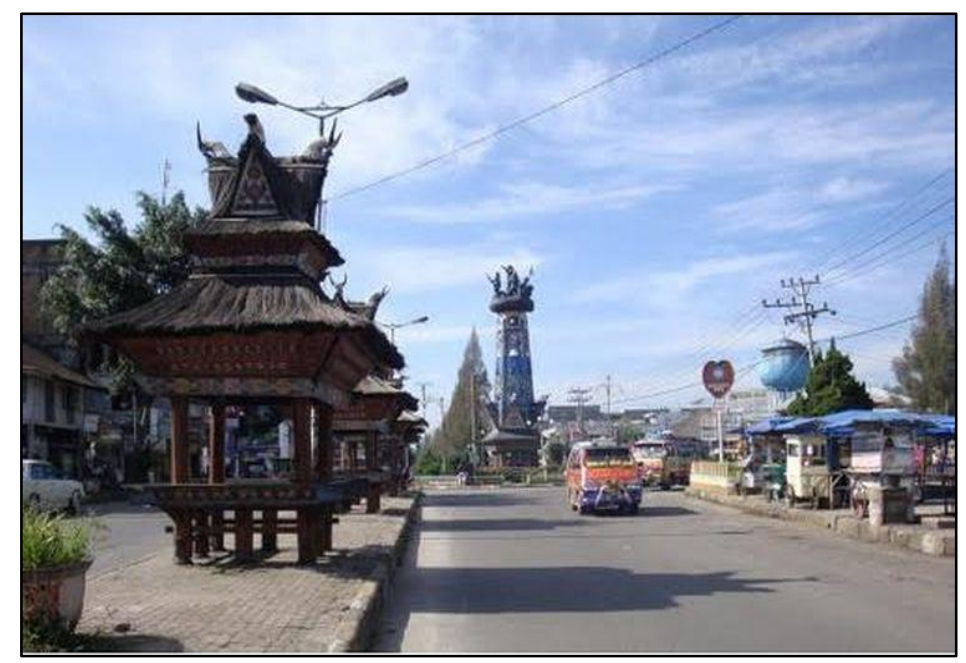

Figure 5 Research Area

Settlement development virtually heads to realizing settlement conditions urban and rural areas healthy and very liveable, safe, comfortable, peaceful, and sustainable so that it is created enhancement public welfare. On the other side, there is a residential environment has been growing relatively very fast with a high total population, so that tends to result in residential environment get rundown (slum area) because of limited availability of necessary infrastructure and facilities [11]. The high housing necessary and habitation in the city make more impact growing of new slum area [12]. This matter describes that need for land and space for shelter business activities are very increasing when the availability of land and rooms in the city increasingly limited, on the other side high tendency of society who wants to live close to the downtown, so that can make it easy to find a job. When the hinterland, many have vacant land and not much many residential areas. When viewed from the plateau can see intensiveness housing in the city area. Whilst the verge area only have landed like gardens, swamps, and rice fields (Figure 6).

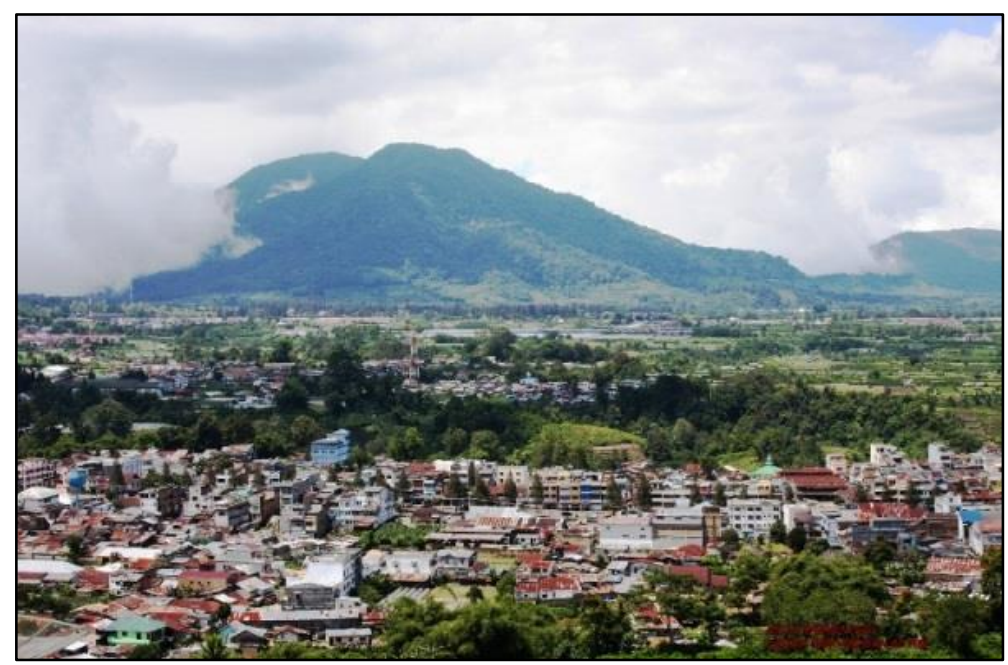

Figure 6 Research Area 


\section{Methodology}

The study aims to find the environment knowing and the atmosphere is there in Berastagi subdistrict that was developed with approach local culture. Although Berastagi sub-district only has an area of $30,5 \mathrm{Km}^{2}$ and including the smallest area which consists of six villages and four villages district [13]. But being one of the site areas played a big role in improving the economy in Karo district. This is because so many tourists visiting this area. In the following figure, you can see level several villages/ villages sub-districts in the Berastagi sub-district (Figure 7).

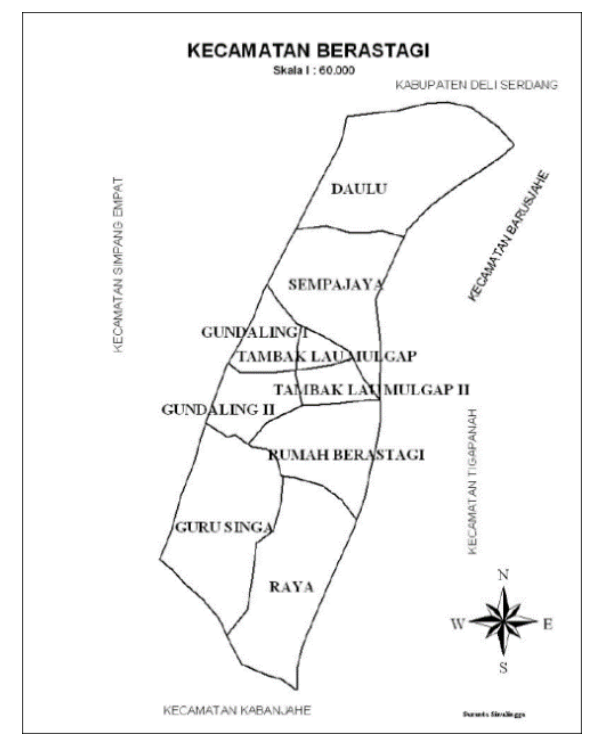

Figure 7 Research Area

The majority of the population is the Karo tribe and the rest Toba Batak tribes, Nias, Java, Aceh, Simalungun, Chinese descent, Pakpak, Dairi, and others. The Karo People hold on tight noble customs, is capital that can be used in the development process [14]. The area and land use in the villages sub-district owned by Berastagi sub-district (Table 1).

Table 1 Villages Regional in Kabupaten Karo

\begin{tabular}{lllllll}
\hline No. & $\begin{array}{l}\text { Villages/ Villages sub- } \\
\text { districts }\end{array}$ & $\begin{array}{l}\text { Regional } \\
\text { Area Km }\end{array}$ & $\begin{array}{l}\text { Paddy } \\
\text { Fields } \\
\text { (Ha) }\end{array}$ & $\begin{array}{l}\text { Non- } \\
\text { Rice } \\
\text { Fields }\end{array}$ & $\begin{array}{l}\text { Non- } \\
\text { Agricultural } \\
\text { Land }\end{array}$ & $\begin{array}{l}\text { Total } \\
(\mathrm{Ha})\end{array}$ \\
\hline 1 & Gurusinga & 6,00 & 0 & 441 & 159 & 600 \\
\hline 2 & Raya & 5,00 & 0 & 368 & 132 & 500 \\
\hline 3 & Rumah Berastagi & 3,50 & 0 & 258 & 92 & 350 \\
\hline 4 & Tambak L.Mulgap II & 1,00 & 0 & 74 & 26 & 100 \\
\hline 5 & Gundaling II & 2,00 & 0 & 148 & 52 & 200 \\
\hline 6 & Gundaling I & 2,00 & 0 & 148 & 52 & 200 \\
\hline 7 & Tambak Lau Mulgap I & 1,00 & 0 & 74 & 26 & 100 \\
\hline 8 & Sempajaya & 4,90 & 0 & 361 & 129 & 490 \\
\hline 9 & Doulu & 3,50 & 177 & 139 & 34 & 350 \\
\hline 10 & Lau Gumba & 1,60 & 0 & 118 & 42 & 160 \\
\hline & Jumlah & 3.050 & 177 & 2.129 & 744 & 3.050 \\
\hline
\end{tabular}


From the table 1, it can be seen that most of the land in the Berastagi sub-district is non-rice fields, which means there are gardens, fields, forests, and many others. Then followed by nonagricultural land, which means land to comply with human needs as a place to live, area of productions such as buildings, houses, and yards. Meanwhile, the use of land as a paddy field is only a small part of Berastagi sub-district.

The state of a residential building is irregular; the quality of the drainage is not following the technical requirements in terms of the channels and their maintenance [15]. Beside many houses, there are still less suitable for habitation and lack of arrangement/ development of residential environmental infrastructure. Made the Berastagi sub-district unable to become a developing area. If problems as mentioned above and the people were more aware and caring, the Berastagi sub-district was one area that could develop.

\section{Result and Discussion}

This study aims to determine the environmental aspects and atmosphere in the Berastagi subdistrict, which are developed with a local wisdom approach. Can be seen from the high level of public awareness of the traditional Karo culture in the Berastagi sub-district. Starting from tourist attractions, house buildings, and even along the road, you can see the conventional Karo nuances.

Construction and development of residential growth centres in rural and agropolitan areas need to be done in stages so that, later on, between regions has potential and complement. Although this area has an uneven soil structure, when a house is built and building regularly, it will not cause a seedy impression and will look neater. Added with optimal drainage flow starting from the channel and maintenance will assist reduce standing water that occurs due to rain and others.

\section{Introduction}

Although Berastagi sub-district located in highlands of North Sumatra which has an uneven soil structure, but have high population density, because it is a community destination for tours. In urban areas are the most densely populated areas inhabited by residents and migrants from other regions. The majority of the population is the Karo tribe and the rest Toba Batak tribes, Nias, Java, Aceh, Simalungun, Chinese descent, Pakpak, Dairi, and others. The spatial settlement formation in this area the concept mostly apply to Karo culture, which is the native tribe of this area.

Most of the land use in Berastagisub-district is dry land (field and garden), rice field, forest, grassland, unplanted swamp and much more. The state of a residential building is irregular, besides that the quality of the drainage is not following the technical requirements in terms of the channels, and their maintenance makes the environmental quality impact look unclean and 
tidy. Add more the high housing needs and settlement in the city make more impact growing of new slum area in Berastagi sub-district. Fortunately, this area has many trees and cold air temperature, so that it does not make Berastagi sub-district dry and hot.

\section{REFERENCE}

[1] “Toba Lake, Indonesia,” 2014, [Online]. Available: https://worldfortraveller.wordpress.com/2014/01/17/toba-lake-indonesia/

[2] "Provinsi Sumatera Utara," 2019, [Online]. Available: https://kompaspedia.kompas.id/baca/profil/daerah/provinsi-sumatera-utara

[3] "Informasi Umum Tentang Tanah Karo," 2017, [Online]. Available: http://www.geocities.ws/merga_silima/regional.htm

[4] "Profil Kabupaten Karo," 2019, [Online]. Available: http://sippa.ciptakarya.pu.go.id/sippa_online/ws_file/dokumen/rpi2jm/DOCRPIJM_1479 108450Bab_2_Lap_AKHIR_RPIJM_Karo_Rev00.pdf

[5] Badan Pusat Statistik Karo, "Kecamatan Berastagi Dalam Angka 2020,"

[6] Nelvia Mustika Sari Gea and Kamarlin Pinem, "Agihan Daerah Rawan Longsor Lahan di Sebagian Wilayah Kabupaten Karo Provinsi Sumatera Utara," Jurnal Pendidikan IlmuIlmu Sosial, 2017.

[7] Zhilli Izzadati Khairuni dan Kiki Lestari, "Kriteria Pengembangan Desa Agrowisata Berbasis Masyarakat Pada Desa Lau Gumba Kecamatan Berastagi," Journal Of Universitas Panca Budi Architecture, 2019.

[8] Lalu Mulyadi, Ida Bagus Suardika and I Wayan Mundra, "Formasi Spasial Permukiman Komunitas Hindu di Dusun Sawun dan Dusun Jenglong Kecamatan Wagir Kabupaten Malang,"2015, [Online]. Available: https://core.ac.uk/download/pdf/198115936.pdf.

[9] “Kabupaten Karo,” 2017, [Online]. Available: https://id.wikipedia.org/wiki/Kabupaten_Karo

[10] Yohanes Djarot Purbadi, "The Clan Formation and The Spatial Formation on Dawanese Settlement Architecture of Kaenbaun Village In Timor Island," 2010

[11] Selly Veronica, Nurlisa Ginting, and Amy Marisa, "Local Wisdom-Based on Development of The Environment and Atmosphere Aspect of Berastagi Night Tourism," 2020, [Online]. Available: https://talenta.usu.ac.id/ijau/article/view/4515/3164

[12] Irma Indriani, "Formasi Spasial Permukiman Kumuh Kota Studi Kasus: Perubahan Pola Ruang Bermukim Pada Lahan di Jalan Sersan Sani Palembang,” 2017.

[13] Badan Pusat Statistik Kabupaten Karo, "Kecamatan Berastagi Dalam Angka 2017," 2017, [Online]. Available: https://karokab.bps.go.id/publication/download.html?nrbvfeve=YWZiOGMwNjZiYzUz ODk2Nzk3YTY1YmEx\&xzmn=aHR0cHM6Ly9rYXJva2FiLmJwcy5nby5pZC9wdWJs aWNhdGlvbi8yMDIwLzA5LzI4L2FmYjhjMDY2YmM1Mzg5Njc5N2E2NWJhMS9rZ WNhbWF0YW4tYmVyYXN0YWdpLWRhbGFtLWFuZ2thLTIwMjAuaHRtbA\%3D\% 3D\&twoadfnoarfeauf=MjAyMC0xMS0xOSAxMDoyNToyOA\%3D\%3D 
[14] "Sejarah Berkembangnya Agama Islam di Tanah Karo Sumatera Utara Pada Tahun 1980-2010," 2012, [Online]. Available:

http://digilib.unimed.ac.id/17575/7/7.\%20NIM.\%20308321014\%20Bab\%20I.pdf

[15] "Rencana Pembangunan Infrastruktur Cipta Karya," 2019, [Online]. Available: http://sippa.ciptakarya.pu.go.id/sippa_online/ws_file/dokumen/rpi2jm/DOCRPIJM_147 9108756Bab_7_Lap__AKHIR_RPIJM_Karo_Rev02.pdf 